\title{
Social Media, Public Participation, and Digital Diplomacy
}

\author{
Ari Darmastuti ${ }^{1, *}$ Astiwi Inayah ${ }^{2,}$ Khairunnisa Simbolon ${ }^{3,}$ Moh. Nizar ${ }^{4}$ \\ 1,2,3,4 International Relations Department, Universitas Lampung \\ *Corresponding author. Email: ari.darmastuti@fisip.unila.ac.id
}

\begin{abstract}
Social media may have roles in improving government performance in digital diplomacy, roles which may be performed by government or non-government actors. The success of Indonesia's digital diplomacy may be achieved through public or community participation. This research put emphasis on public participation of the Indonesians in digital diplomacy through their uses of social media (Facebook, Instagram, Whatsapp, Youtube), Websites, and Applications made by the Government. This research uses documents as the main source of data. Research results show that Indonesians, both in Indonesia and abroad, especially through diaspora organizations, participate in promoting Indonesia, thus participating in digital diplomacy for the interests of Indonesia. The results also that high uses of internets by Indonesians (48\% out of 270 millions) is an opportunity for further public participation in digital diplomacy, especially for public aspiration articulation, decision making, and communication involving stakeholders on public diplomacy. It is also an opportunity for publics and government to access data from other countries, to promote Indonesia to foreign countries. However, high uses of internet and social media by Indonesians can also be used by radicals to spread their ideas, for foreign actors to attack Indonesian domestic interests, to spread pornographic contents, and online frauds, both domestically or in international arenas.
\end{abstract}

Keywords: Social Media, Public Participation, Digital Diplomacy.

\section{INTRODUCTION}

In the last fifteen years (2002-2017), the number of internet users worldwide increased more than three times, reaching about 3,6 billions. This data shows us that social interaction has been changing drastically: communities changed into networked communities or networked societies [1]. This 2017 data has also been changing drastically in the last 4 years into 4.66 billions, or $59.5 \%$ of the world population in 2021. Over this number, 4.32 billions $(92.6 \%)$ access the internet through their mobile phones [2]. We could say that almost all world populations are connected to each other, and information flows freely. Information can be gathered, stored, processed, managed, and dispatched in a totally different format compared to what happened in the past.

The high number of internet users worldwide also shows that there is a good chance for involving the public to improve government performance in public diplomacy, especially digital diplomacy. Digital diplomacy which uses social media is expected to be optimized by common people, or the public. This also may be used by the government of Indonesia to involve Indonesians living in Indonesia or abroad to improve its diplomacy by using digital platforms to promote Indonesia, thus being digital diplomats.

The opportunity to increase public participation on digital diplomacy for the interest of Indonesia is made possible by data which show us that Indonesians use social media platforms such as twitter, instagram, facebook, whatsapp, and youtube not only for the purpose of entertainment but also for assessing information. These platforms are in fact already being used by diplomats to increase government performance to disperse information to Indonesians living abroad on real time speed. The speed of digital technology is also used to improve speed of the decision making process with regards to diplomatic purposes [3]. 
Indonesia, as other countries, is also a country which uses digital technology for diplomatic interests. According to a survey (Digital Diplomacy Review 201), Indonesia ranked 38th among 209 countries on the use of digital technology for digital diplomacy. Indonesia is only behind some countries with high use of technology for their diplomatic purposes such as France, United Kingdom, Japan, and India. And Indonesia is above other Asian countries in this regard. According to another research, Universitas Gadjah Mada Center for Digital Society, Indonesia ranked $9^{\text {th }}$ among 203 countries using digital technology for digital diplomacy [1].

Other countries such as the Unites States of America and Australia has been starting the use of digital diplomacy in a much earlier period than Indonesia. They had developed infrastructure to support their digital diplomacy. The United States of America, the pioneer of digital diplomacy in the world, developed a specific task force for ediplomacy inside the Office of State Secretary in 2002 [1].

As a new field of study in international relation, digital diplomacy has become the interest of some researchers. Westcott (2008) conducted a research about the influence of internet use towards international relation [4]. Meanwhile Adesina (2017) conducted research about digital diplomacy and foreign policy, Madu (2018) studied problems and challenges of digital diplomacy in Indonesia [5] [6]. Other researchers having interests about digital diplomacy are Melissen (2017) who studied critical digital diplomacy, Viona (2018) who studied benefits and risks of digital diplomacy, Asadi (2017 and 2021) conducted researches about the roles of digital medias on democracy, and lastly Wright and Guemna (2020) studied gender and digital diplomacy in Europe [7] [8] [9] [10].

Those researches show us that digital diplomacy is an important issue in the study of international relations. However, those researches also show us that public or community roles in digital diplomacy has yet been included as part of their research. That is why our research puts public participation as our focus of study. Other than public participation, we also put attention on the opportunity and challenges faced by Indonesia for the implementation of digital diplomacy for its interests in international relations. We hope this research can contribute valuable insights for both academic and practical purposes, contribute insights for the debate of digital diplomacy in a developing country and also for the potential of involving more Indonesians to participate in digital diplomacy as internet and digital technologies have become daily reality in public life.

\section{THEORETICAL FRAMEWORK}

\subsection{Social Media and Digital Diplomacy}

Hanson (2012) defines digital diplomacy as "the use of the Internet new information communication technologies to help achieve diplomatic objectives. The UK Foreign and Commonwealth Office define digital diplomacy as "solving foreign policy problems using the internet"; the Office of Secretary of State in the USA defines digital diplomacy as "the $21^{\text {st }}$ Century statecraft"; the Canadian Department of Foreign Affairs, Trade and Development calls it “Open Policy”[11].

Potter stated that digital diplomacy is a practice of diplomacy using digital technology based networks. The technology consists of internet, mobile devices and social media channels. The concept of digital diplomacy which stresses the use of social media often links digital diplomacy with the internet and social media for diplomacy. Digital diplomacy is also often called ediplomacy, cyber diplomacy, or twiplomacy [12]. Regarding the roles of digital diplomacy, Dizard (2001) summarized three roles: first, develop issues on foreign policy which involve sophisticated technologies in gathering and using information. Second, organize and change information sources related to the Office of Foreign Affairs and it's various bureaus overseas. Third, to influence public opinion as well as to channel the interest of the public to take a role in public diplomacy [13].

Form of digital diplomacy is categorized into a more specific form which is called social networking sites or SNS. SNS is defined further as a web based system that enables an individual to form a public or semi public profile, and enables individuals to draw users list that can do common-sharing. It also enables an individual to check users' lists whether users create him/herself or by others [14].

Digital diplomacy, according to Hanson, has 8 general objectives: (1) knowledge management in which digital diplomacy is used to gather information from all stakeholders to achieve institutional objectives; (2) to do public diplomacy (to keep communication with citizens living abroad and to influence other online medias as well by: (3) Information management: to manage information and to use information in decision making and in responding towards development of social and political situations: (4) Communication and consular responses: to conduct communication with citizens living abroad for important, critical and emergency situations; (5) Disaster responses: to be used as 
communication in disaster countermeasures ;(6) Internet free do to be used as a platform to evaluate freedom of expression and democracy; (7) External resource: to enlarge opportunities to achieve national interests; and (8) Policy planning to be used for optimizing coordination and planning process in achieving national interests [12].

\subsection{Social Media and Public Participation}

Social media is a communication platform to be used in social processes. Social media can be used to collect information fastly and completely. In the progress, social media has become a daily activity of people to connect to the outer world, outside their homes. It is needed and beneficial to almost all people now-a-days. Social media is online media to support social interaction. It is a web-based technology which changes communication into interactive dialogues. Some popular social media platforms are Whatsapp, Facebook, Youtube, twitter, Wikipedia, blog, etc. Social media is also defined as a virtual world in which the users can participate easily, create and share messages. Among others, it includes blog, social network, online wiki/encyclopedia, and virtual forums [15].

Social media has several functions: (1) to enlarge social interaction using internet and web technology; (2) to transform communication practice from "one to many" to "many to many"; (3) to democratize knowledge and information in which common people can not only, create and share but also clarify information on real time bases. Social media can be identified based on the natures of its usage: (1) website collaboration project in which users are allowed to change, add, or delete contents on the web; (2) blog or microblog in which users may freely express feelings, experience, statements, and even critics such as twitter; (3) contents in which users in the web may reciprocally share multimedia contents such as ebooks, videos, photos, pictures, etc such as youtube; (4) social network sites in which users are allowed to be connected by making and sharing private information such as facebook; (5) virtual game world in which users appear on avatar form using 3D application and use the avatar form to interact with others in real interaction, as in online game; (6) virtual social world is an application in the form of virtual world to interact with other as in second life [16].

In short, the term "social" in social media indicates that common people, or public, or community members, are unseparated actors of social media. It is called social media since public, common people are the main actors of the use of the media, both as active participants who create and share informations and passive actors receiving those information through social media. That is why this research about public participation on digital diplomacy is defined as the participation of common people or public on diplomacy using digital medias. And as diplomacy is defined as the process by which a country achievesits interests through promotion in foreign countries, then public participation in digital diplomacy is defined as the participation of common people or public to help it'scountry to achieve its objective by promoting their country in foreign work using digital media.

\section{METHOD}

The method used in this study uses a qualitative approach. This study describes public participation in digital diplomacy, public opportunities to implement public diplomacy through social media, and challenges in implementing digital diplomacy through social media. This qualitative research uses documents as the main source of data. The documents were from reports of official institutions, organizations, as well as individuals. The documents were also from publications, other research results, webs, etc.

Data were analyzed from the initial period of data collection. The first stage of data analysis is data condensation. Data condensation is the process of collecting data through selection and focusing. Then, the second stage is the presentation of data in the form of explanatory texts related to research. The third stage is drawing conclusions, and verification. At this stage, conclusions are drawn to describe the findings using the concepts or theories used. Then, verification is carried out to ensure that the conclusions drawn are credible. [17] [18].

\section{FINDINGS AND DISCUSSION}

\subsection{Public Participation in Digital Diplomacy}

Before we present data and analysis of public participation in digital diplomacy, here, first of all, we will present data regarding the implementation of digital diplomacy by the Government of Indonesia (GOI). According to data from a research (Sapta Dwikardana, Anggia Valerisha, Sylvia Yazid (2018)), the GOI has implemented a "middle stage level" of digital diplomacy and used for the interest of protecting Indonesian migrant workers abroad [19]. Some social media platforms used by the Ministry of 
Foreign Affairs such as Safe Travel, SMS Blasts (for the interest of work safety of Indonesian migrant workers), social media applications by the Ministry of Manpower and the Board for Service and Protection of the Indonesian Migrant Workers (Badan Pelayanan dan Perlindungan Pekerja Migran Indonesia/BP2MI). The Ministry of Foreign Affairs also developed an official website as well as facebook, twitter, instagram, and youtube for diplomatic purposes. The other two Indonesian institutions, the Ministry of Manpower and BP2MI developed almost similar social media platforms for the protection of Indonesian workers abroad as well as for their interests in the international arena.

Apart from official uses of social media by government institutions, Indonesians overseas are also involved in conducting public diplomacy. According to one source (Aritonang 2017), Indonesian Diaspora Network Netherland (IDN-Nl) which consists of $5 \%$ of total Indonesian diasporas worldwide conducted public diplomacy activities through the establishment of certain task forces and partnership projects [20]. Among those task forces were health task force as part of Indonesian Diaspora Global Network Health (IDGNH); (2) City Feasibility Task Force which focus on the improvement of cities condition in Indonesia; (3) immigration and citizenship task force focusing on double citizenship agenda to help Indonesian diasporas residing in Netherland to be able to be active overseas without losing Indonesian Citizenship; (4) culinary task force; (5) youth and education; (6) migrant worker task force; (7) task force for Maluku which focus on the issue of improving Maluku descends Netherlanders with the Province of Maluku in Indonesia; and (8) art and culture.

Some activities of the use of the internet to support Indonesian interest in foreign countries is also apparent among the people who post using Wonderful Indonesia Hashtag. Some 9,938,421 people involved in promoting Indonesian tourism abroad by putting Wonderful Indonesia hashtag, thus promoting Indonesia abroad [21]. Next are some pictures posted in Wonderful Indonesia by Indonesians:

Other than Netherland Diasporas, the website of Indonesian Diaspora Network (IDN) Global shows some activities. The website provides information regarding Indonesian diasporas overseas. The website also functions as online media to mediate inputs and suggestions from any Indonesian diasporas around the globe. The diasporas can give inputs and suggestions through "contact Us" menu. They can also fill in their names, phone numbers, addresses, and messages. The website functions mostly to improve multilateral communications between Indonesia and around the globe Indonesian diaspora; integrate ideas, solutions and networks to improve public welfare, especially the diasporas'; contribute supports for Indonesian community in general through their activities and programs as stated in their vision and mission, as well as programs they developed for the organization.

Other than that, social media was also used by the Indonesian Embassy in the Hague, with other 40 embassies, to promote Indonesia through Indonesian Embassy participation in the Embassy Festival 2020 in Netherlands. The embassy Festival 2020 was held on a virtual platform due to the covid-19 pandemic. The virtual cultural festival which was held on 4 September 2020 promoted Indonesia through music, dances, food and culinary. This virtual cultural festival drew 15.000 online visitors/spectators. As part of those cultural festivals, online visitors could also order cooking recipe booklets provided by the Indonesian Embassy in the Hague [22].

Indonesian diasporas in Australia also participated in digital diplomacy. Their participation varied, and among other was the use of their facebook website to raise funds for the purpose of collecting donations to be sent home, to the people of Indonesia, especially to the victims of disasters. One example was their success in collecting AUD\$18.200 for the victims of the tsunami disaster in West Sulawesi in 2018. Indonesian diasporas in Australia consisted of 6276 members [23].

In South Africa, Indonesian diasporas were also active in promoting Indonesia through promotion of Indonesian culinary. To promote Indonesia in South Africa, the organization of the diasporas invited popular cooks from Indonesia to give cooking tutorials on online cooking classes and cooking clinics [24].

Other than those regional diasporas, Indonesians living abroad also established a group called GenWI which stands for Generation of Wonderful Indonesia. The purpose of the group is to promote Indonesian tourism, trade, and investment. In Asia, the countries included in this group are South Korea, India, China, Thailand, Malaysia, Singapore. They also initiated the opening for the Australia chapter of GenWI [25].

The activities of Indonesian diasporas are supported by the use of social media platforms by Indonesia's government institutions, especially the Ministry of Foreign Affairs" "Safe Travel" [26]. Other institutions supporting Indonesian diasporas through social media are the Ministry of Manpower and Transmigration and Board for Indonesian Migrant Workers Protection [27] [28]. 
In short, data show that Indonesians or the public are actively involved in public diplomacy through the use of social media platforms. Data also show that the participation came from almost all over the world. This means that the public are involved in conducting public diplomacy for the interest of the Republic of Indonesia in foreign countries.

The emergence of non-state actors and the concept of multi-track diplomacy have also led to more public involvement in digital diplomacy. The public as nonstate actors also have the ability and access to conduct diplomacy through content published through social media. Thus, the public becomes one of the important actors in the implementation of digital diplomacy.

\subsection{Public Opportunities for the Implementation of Public Diplomacy Through Social Media in Indonesia}

Up to 2014, internet users in Indonesia comprised 83.7 millions [29]. Raised to 171,17millions in 2019 in which $95 \%$ used the internet for social media purposes [30]. In the Digital Diplomacy Ranking Indonesia ranked 41 compared to all other nations in the world; while according to a study conducted by Gadjah Mada University research team. Indonesia was among other European tech-savvy countries such as France and the United Kingdom [1].

The Data shows that active users of facebook in Indonesia was 65 millions, 19.5 twitters users, 700.000 users of path, and 10 millions users of Line, and linkedin 1 million users [1]. Meanwhile Instagram users in Indonesia were only behind the United States and Brazil [31]. These data shows there is a big opportunity for the GOI to involve the public in digital diplomacy as stated many times by the President of Indonesia on some occasions such as APEC Business Advisory Council meeting in Papua New Guinea in November 2018 [32]. The GOI, through the Ministry of Foreign Affairs Regional Conference on Digital Diplomacy (RCDD) Forum which was followed by 10 ASEAN countries and other six countries from the surrounding regions; Australia, India, Japan, South Korea, Chin, and New Zealand. The Conference was aimed to improve digital technology use capabilities for digital diplomacy [33].

It is critical for the GOI to involve the public in digital diplomacy since some incidents show us it is critical that GOI to maintain quick contact with Indonesians living abroad such incidents of conflict involving one Malaysian businessman humiliating Indonesian company Gojek which evolved into mass protests in Indonesia and Malaysia. Incident of Indonesian Hajj Pilgrims passports fraught in Philippine, Abu Sayyaf terrorist abduction of Indonesian sailors, abduction of Indonesians in Somalia, violence against migrant workers abroad, even Rohingya issues which proves to draw strong reactions among Indonesians.

Apart from those issues, public participation on digital diplomacy is also critical since Indonesian ecommerce is among the biggest in Asia, especially in South East Asia with 30 billions dollars in 2019 [15]. The use of social media is also critical to link Indonesian start-ups such as Shopee, Lazada, Grab, JdId, Tokopedia, Bukalapak, Gojek to penetrate markets, especially in South East Asia where most Indonesian migrant workers and diasporas stay.

The use of social media is also important for the GOI to access information from the websites of other countries, information which may be crucial to develop critical policies in international arenas or for bilateral policy options such as developing bilateral cooperations in social, economic, cultural and other aspects. In terms of efficiency, the use of social media also speeds up communications among government institutions with bilateral or multilateral partners as well as the Indonesian communities and the public in general [34]. Other advantages of the use of social media for public and digital diplomacy are the opportunity to keep contacts and communication with Indonesian diasporas, to use information from other countries, for promoting Indonesia.

\subsection{Challenges for the Implementation of Digital Diplomacy through Social Medias}

Apart from its' advantages, public participation on digital diplomacy has also led to some problems and also was faced with some challenges for Indonesia. The following paragraphs will present these problems and challenges.

\subsubsection{Use of Social Medias by Other Countries to Attack Indonesian Interests}

The ease of the use of social media was also opening more rooms for the attack by public from other countries, or cyber crime, illegal mis-use of data. Some past incidents such as the incident of Bali Nine in 2005 in which drug smuggler was indicted of commiting the crimes and was supposed to be executed by capital punishment in 2015 due to the magnitude of the crime, was finally released due to very strong attack from wide range of public from almost all over of the world. These social media 
attacks resulted from the use of social media diplomacy by the Australian public in general as well as the government of Australia who threatened to stop their aids should the Government of Indonesia execute the criminal. This kind of problem is not easily solved since it can lead to many problems for Indonesia, especially for the interest of the Province of Bali which is highly dependent on tourists from Australia.

\subsubsection{The Development of Radical Websites}

Other than that incident, the use of social media for digital diplomacy also opened up rooms for the fast development of radical websites in Indonesia. Police cyber crime task force as well as anti-terorism task force has long noticed the use of social media to recruit new members of radical groups, to spread radical content messages, to inflict radical ideologies, and to spread hate messages, anti government messages, pro khilafah messages, and even to conduct activities to inflict fear in the community. A survey by the Student Creativity Program of Universitas Pendidikan Indonesia revealed that 44 out 100 high school students in Bandung, West Java (samples were chosen through cluster sampling method) were affected by radical ideologies. The study also revealed that the students were affected by messages through internet and social media platforms. Other than social media platforms, the students were also exposed and affected by radical messages through family and friends. And as social media are borderless, the radical messages of course come from national or international sources [35]. Apart from its potential to be used to spread radical content, the General Director of Islamic Education in the Ministry of Religious Affairs of the Republic of Indonesia stated that social media can also be used to spread the messages of moderate religious, especially Islamic, values to students and other youths [36].

Another challenge of the use of social media is pornographic content messages, especially with the purpose to exploit and to harass youths and children. A study by the Ministry of Information of the Republic of Indonesia in 2014 with the title Digital Citizenship Safety among Children and Adolescents in Indonesia found that most of the 400 children samples taken for the study were exposed (mostly unintentionally) to pornographic contents while accessing information [37].

Social media were also proven to be used to conduct digital black campaigns which threaten peaceful democratic life especially in the periods preceding elections. The black campaigns were so fierce, especially in the last two presidential elections in 2014 [38] that almost tore the country into two pieces, supporters and opponents of the two strongest candidates. The black campaigns ranged from the spread of hoaxes up to serious effort to distort and mislead publics as well as creating fear of real conflicts among community members. According to data from the Ministry of Information of the Republic of Indonesia, 800.000 sites involved in spreading hoaxes [39].

\subsubsection{Indonesian Digital Civilization}

The civility of digital social media users is also a challenge for Indonesian digital diplomacy. Based on the results of a survey conducted by Microsoft, Indonesia has a very low digital civility index ranking. The survey involving 16,000 respondents from 32 countries in April-May 2020 showed that Indonesia was ranked 29th along with Mexico as the country with the lowest civility index in the world. Consists of a total assessment of the intrusive index, behavior, sexual, reputation, pain, concern, frequency of more than three times, consequences, actions taken, last week/month. Indonesian netizens often carry out acts of discrimination, bullying, hatred against religious figures, the government, actresses, and other actors. Then, as many as $47 \%$ surveyed admitted that they had also bullied others through social media. Meanwhile, another $19 \%$ have experienced bullying from other social media users. Millennials are the main target for bullying on social media with a percentage of $54 \%$ in 2021 . Therefore, the civility of digital social media users in Indonesia still needs to be improved [40].

The current level of digital civilization in Indonesia can affect the image of Indonesia's digital diplomacy participation. The image of Indonesian people in the real world is known to be inverted with the image in cyberspace. Sometimes there are acts of discrimination, bullying, hate speech committed by social media users in Indonesia. This can be due to the lack of digital literacy obtained by social media users. Digital literacy is the ability to use information and communication technology to find, create, and learn information by means of cognitive, technical, and appropriate [41]. Digital literacy aims to equalize views on behavior in using social media, through the exchange and validation of various knowledge/information on social media. Based on the digital literacy index, Indonesia is at 3.47, which means it is at a moderate level in 2020 [42]. However, according to the Director General of Information Applications at the Ministry of Communication and Informatics, Semuel Abrijani Pangerapan, this figure is not yet at a good level [43]. The government together with creative cyber and 
other stakeholders still need to increase digital literacy directly to the Indonesian people.

\subsubsection{Use of National Language on Social Media Accounts and Content}

The language used on websites, social media accounts, and official government accounts as well as actors participating in digital diplomacy in Indonesia still use the national language [44]. This is one of the challenges in digital diplomacy to determine the target audience. If the target audience for digital diplomacy is foreigners, then the use of Indonesian on accounts that create digital diplomacy content is still not appropriate. The use of multiple languages in digital diplomacy content is still a bit in Indonesia. Thus, it is difficult for foreigners to understand the meaning of the diplomatic content that has been created. Unlike the case with what has been done by the United States Department of State. They created ten twitter accounts in ten different non-English languages. The languages of the ten Twitter accounts are Arabic, Mandarin, Urdu, Hindi, Persian, Spanish, Portuguese, Russian, French, and Turkish. It is intended that audiences from these countries can understand the information distributed by the United States Department of State. This method has proven to be more effective for US digital diplomacy [45]. Therefore, the use of multi-language on social media accounts and digital diplomacy content in Indonesia needs to be built.

\section{CONCLUSIONS}

Our study with the title "Social Media, Public Participation, and Digital Diplomacy" shows us that the Indonesian community, or publics, were involved actively in digital diplomacy. Our data and analysis show us that Indonesians, both inside the country and outside ones, especially through organizations of diasporas from several regions in the world actively involved in promoting Indonesian interests outside the country. They promoted Indonesia's interests through the use of their social media platforms to interact with members, to plan and promote activities, to interact with Indonesia's embassies both for their own interests and for the interests of Indonesia's embassies as the representative of the Government of the Republic of Indonesia to communicate and serve the diasporas, to plan policies and other governmental institutional interests.

Social media were also used by the diasporas to promote investment opportunities in Indonesia by providing necessary information through booklets or other online sources they provide in cultural events Social media were also used to promote cooperation activities in the field of health, education, disaster mitigation, and economy.

Apart from those, social media was also used by government institutions to communicate with Indonesians in foreign countries. Social media were also used to communicate among diplomatic communities, to collect information from other countries in order to develop cooperation interests. Bargaining position in negotiations also helped by the use of social media.

Apart from those positive roles, social media also contributed certain problems and challenges. Those problems were the surge of radical websites, the use of social media by foreign countries to attack Indonesia's national interests. It also opened up rooms with pornographic contents targeted at youths and children. Other than that, social media were also used for black campaigns, spreading hoaxes in at least two presidential elections. This last issue may lead to a serious problem for the future of democracy in Indonesia. Further, it may endanger Indonesian democracy in the eyes of the international community. Then, a negative campaign was also carried out by the regional WHO in the Eastern Mediterranean region which led public opinion not to consume saturated fats including palm oil and disseminated it through its official website. This can threaten Indonesia's interests in the business sector, especially palm oil exports to the Eastern Mediterranean region.

Then, the civility of digital social media users is also a challenge for Indonesian digital diplomacy. Indonesian people who use social media often carry out acts of discrimination, bullying, hatred against religious leaders, the government, actresses, and other actors. Thus, the digital civilization index ranking is very low and the image of the Indonesian people in the international world is also not good. The use of National Language in Social Media Accounts and Content is also a challenge. The majority of websites, social media accounts, and official Indonesian government accounts still use the Indonesian national language. Therefore, the target audience for Indonesia's digital diplomacy is not yet clear.

This study suggests that the government should tighten digital security, especially on websites that are illegal and violate the law. The need for regular and continuous tracking to detect sites that spread negative content. Such websites should be blocked immediately. Then, it is also necessary to increase digital literacy for Indonesian people who use social media. Digital literacy can be done virtually or nonvirtually using content that is creative and easy to 
understand by the whole community. Digital literacy must also be carried out regularly and continuously so that indonesian digital civilizational is also getting better and wiser in using social media in order to maintain a good image of Indonesia in the international world. Determining the target audience for digital diplomacy is also very much needed by the Government of Indonesia. Social media accounts and state-owned websites should create multilingual content. Thus, the target audience of digital diplomacy activities that are made is appropriate.

\section{REFERENCES}

[1] A. Prabandari and V. Rahyaputra, "What is Digital Diplomacy and Why Indonesia Should Embrace It?," The Conversation, 2018. https://heconversation.com/what-is-digital diplomacy-and-why-indonesiashouldembrace-it-89327 (accessed August 12, 2021).

[2] Statista 2021, "Global Digital Population as on January 2021," Statista, 2021. https://www.statista.com/statistics/617136/dig ital-population-worldwide/ (accessed August 12, 2021).

[3] Universitas Gadjah Mada, "Diplomasi Harus Menjawab Tantangan Era Digital," UGM, 2017. $\quad$ https://ugm.ac.id/id/berita/13925diplomasi-harus-menjawab-tantangan-eradigital (accessed August 12, 2021).

[4] N. Westcott, "Digital Diplomacy: The Impact of the Internet on International Relations," Oxford Internet Institute Research Report, 2008.

[5] O. S. Adesina, "Foreign policy in an era of digital diplomacy," Cogent Social Sciences, volume 3, 2017.

[6] L. Madu, "Indonesia's Digital Diplomacy : Problem and Challenges," Jurnal Hubungan Internasional, vol. 7, no. 1, pp. 11-18, 2018.

[7] J. Melissen, "The Case for Critical Digital Diplomacy," Working Paper, 2017.

[8] V. Rashica, "The Benefits and Risks of Digital Diplomacy,", South East European University Review, vol. 13, number 1, pp. 75-89, 2018, doi: 10.2478/seeur-2018-0008.

[9] A. Asadi, "A Role of Digital Media on Discussing about the Diplomacy in the World," Open Journal of Political Science, vol. 7, number 02, pp. 267-275, 2017, doi:10.4236/ojps.2017.72021.

[10] K. A. M. Wright and R. Guemna, "Imagining the European Union: Gender and Digital Diplomacy in European External Relations," Political Studies Review, volume 18, 2020.
[11] T. Yahya, "Digital Diplomacy, Sebuah Kebutuhan Mendesak,". Detik News, 2016. https://news.detik.com/kolom/d3194614/digital-diplomacy-sebuahkebutuhan-mendesak (accessed August 12, 2021).

[12] O.S. Adesina, "Foreign Policy In An Era Of Digital Diplomacy," African Journal For The Psychological Study Of Social Issues, vol 19, number $\quad 3,2016$. http://ajpssi.org/index.php/ajpssi/article/viewF ile/198/pdf_150 (accessed August 12, 2021).

[13] D. J. Wilson, "The Origins of Digital Diplomacy," in Digital Diplomacy: U.S. Foreign Policy in the Information Age. United States of America: Greenwood Publishing Group, Inc., pp. 19 - 36, 2001.

[14] D. M. Boyd and N. B. Ellison, "Social Network Sites: Definition, History, and Scholarship," Journal of Computer-Mediated Communication, vol. 13, pp. 211, 2008.

[15] A. Mayfield, "What is Social Media?," EMarketer, 2008. $<$ https://www.emarketer.com/content/globalecommerce-2019> (accessed August 12, 2021).

[16] A.M. Kaplan and M. Haenlein, "Users of the World, Unite! The Challenges and Opportunities of Social Media,', Business Horizons, vol. 53, number 1, pp. 59-68, 2010, doi: 10.1016/j.bushor.2009.09.003.

[17] Sugiyono, Metode Penelitian Pendidikan Pendekatan Kuantitatif, Kualitatif, dan R\&D. Bandung: Alfabeta, 2010.

[18] L. J. Moleong, Metodologi Penelitian Kualitatif. Bandung: PT Remaja Rosdakarya, 2000.

[19] P. Scoville, A. Letters in S. D. Kardana, Transformasi Strategi Diplomasi di Era Digital: Identifikasi Postur Diplomasi Digital di Indonesia. Bandung: Universitas Katolik Parahyangan, 2017.

[20] A.A. Aritonang, Upaya Indonesian Diaspora Network (IDN) dalam Diplomasi Publik Indonesia terhadap Belanda di Bidang Sosial Budaya tahun 2013-2016, JOM FISIP, vol. 4, number 2, 2017.

[21] S. Kemp, "Digital 2019: Indonesia,”. 2019. https://datareportal.com/reports/digital-2019indonesia (accessed August 12, 2021).

[22] Kedutaan Besar Republik Indonesia Den Haag Belanda, "15.000 Pengunjung Digital Nikmati Tarian dan Kuliner Indonesia di Embassy Festival Belanda," id.indonesia.nl, 2020. https://www.id.indonesia.nl/update/berita/sosi al-budaya/15-000-pengunjung-digital-nikmati- 
tarian-dan-kuliner-indonesia-di-embassyfestival-belanda (accessed August 12, 2021).

[23] Facebook @Indonesian Diaspora in Australia, https://web.facebook.com/IndonesianDiaspora .Australia?_rdc=1\&_rdr (accessed August 12, 2021).

[24] Surat Dunia, "Para Diaspora Indonesia Kembangkan Kuliner Indonesia di Afrika Selatan," Surat Dunia, 2020. https://suratdunia.com/2020/07/03/paradiaspora-indonesia-kembangkan-kulinerindonesia-di-afrika-selatan/ (accessed August 12, 2021).

[25] CNN Indonesia, "Dari Ibu Kota Negeri Sakura, GenWI Jepang Diluncurkan.," CNN Indonesia, 2018. https://www.cnnindonesia.com/gayahidup/20180722162441-269-316090/dari-ibukota-negeri-sakura-genwi-jepang-diluncurkan (accessed August 12, 2021).

[26] Kementerian Luar Negeri Republik Indonesia, "Safe Travel," Kemlu, 2020. https://kemlu.go.id/portal/id/pp/68/safe_travel (accessed August 12, 2021).

[27] Kementerian Ketenagakerjaan Republik Indonesia, https://kemnaker.go.id (accessed August 12, 2021).

[28] Badan Nasional Penempatan dan Perlindungan Tenaga Kerja Indonesia, https://portal.bnp2tki.go.id (accessed August 12, 2021).

[29] Kominfo, "Pengguna Internet Indonesia Nomor Enam Dunia," Kominfo, https://kominfo.go.id/content/detail/4286/peng guna-internet-indonesia-nomor-enamdunia/0/sorotan_media (accessed August 12, 2021).

[30] Kompas.com, “APJII: Jumlah Pengguna Internet di Indonesia Tembus 171 Juta Jiwa,”. Kompas, 2019. https://tekno.kompas.com/read/2019/05/16/03 260037/apjii-jumlah-pengguna-internet-diindonesia-tembus-171-juta-jiwa (accessed August 12, 2021).

[31] Databoks Katadata, "Pengguna Instagram,", Katadata, 2018. https://databoks.katadata.co.id/datapublish/20 18/02/09/berapa-pengguna-instagram-dariindonesia (accessed August 12, 2021).

[32] S. Persada, "Di Forum APEC, Jokowi Pamer Revolusi Industri 4.0,” Tempo, 2018. https://nasional.tempo.co/read/1147402/diforum-apec-jokowi-pamer-revolusi-industri-40/full\&view=ok (accessed August 12, 2021).

[33] Kemlu.go.id, "Konferensi Regional tentang Diplomasi Digital: Platform Kerjasama Kawasan Mengenai Diplomasi Digital,"
Kemlu.

https://kemlu.go.id/portal/id/read/585/berita/k onferensi-regional-tentang-diplomasi-digitalplatform-kerja-sama-kawasan-mengenaidiplomasi-digital (accessed August 12, 2021).

[34] Universitas Indonesia, "Diplomasi Indonesia: Tantangan dan Peluang," Universitas Indonesia, 2019. https://www.ui.ac.id/diplomasi-indonesiatantangan-dan-peluang/> (accessed August 12, 2021).

[35] Z. Wuragil, "Survei Ungkap Paham Radikal Pelajar dari Media Sosial dan Keluarga," Tempo, 2021. https://tekno.tempo.co/read/1502470/surveiungkap-paham-radikal-pelajar-dari-mediasosial-dan-keluarga/full\&view=ok (accessed August 12, 2021).

[36] Indonesia.go.id, "Strategi Menangkal Radikalisme Keagamaan," Indonesia.go.id, 2019. https://indonesia.go.id/narasi/indonesiadalam-angka/sosial/strategi-menangkalradikalisme-keagamaan (accessed August 12, 2021).

[37] Kominfo, "Riset Kominfo dan UNICEF Mengenai Perilaku Anak dan Remaja dalam Menggunakan internet," Kominfo, 2014. https://kominfo.go.id/index.php/content/detail/ 3834/Siaran+Pers+No.+17-PIH-KOMINFO2014+tentang+Riset+Kominfo+dan+UNICEF + Mengenai+Perilaku+Anak+dan+Remaja+Da lam+Menggunakan+Internet+/0/siaran_pers (accessed August 12, 2021)

[38] I. H. Harahap, "Kampanye Pilpres 2019 Melalui Media Sosial dan Pengaruhnya Terhadap Demokrasi Indonesia," Komunikologi: Jurnal Ilmiah Ilmu Komunikasi, vol. 17, no. 1, 2020.

[39] A. Yuliani, "Ada 800.000 Situs Penyebar Hoax di Indonesia," Kominfo, 2017. https://kominfo.go.id/content/detail/12008/ada -800000-situs-penyebar-hoax-diindonesia/0/sorotan media (accessed August 12, 2021).

[40] Microsoft, "Civility, Safety \& Interaction Online: Indonesia," Microsoft. https://www.microsoft.com/en-us/onlinesafety/digitalcivility?activetab=dci_reports:primaryr4 (accessed August 12, 2021).

[41] S. Amanda, "Apa itu Literasi Digital Prinsip ,Manfaat dan Contohnya," Tirto, 2021. https://tirto.id/apa-itu-literasi-digital-prinsipdasar-manfaat-dan-contohnya-gbhL (accessed August 12, 2021).

[42] Kominfo and Katadata Insight Center, "Status Literasi Digital Indonesia 2020," 
https://katadata-s3-public.s3.ap-southeast-

1.amazonaws.com/media/kic/kominfo/Status

\%20Literasi\%20Digital_Nasional.pdf

(accessed August 12, 2021).

[43] I. E. Alamsyah, "Indeks Literasi Digital Indonesia Belum di Tingkat Baik," Republika, 2021.

https://www.republika.co.id/berita/qov1jy349/ indeks-literasi-digital-indonesia-belum-ditingkat-baik (accessed August 12, 2021).

[44] N. Dennis, "Diplomasi Digital Indonesia, Peluang dan Tantangan," Geotimes, 2021. https://geotimes.id/opini/diplomasi-digitalindonesia-peluang-dan-tantangan/ (accessed August 12, 2021).

[45] C. Bjola and M. Holmes, Digital Diplomacy: Theory and Practice. New York: Routledge, 2015. 